\title{
PELATIHAN KADER KESEHATAN DETEKSI DINI STUNTING PADA BALITA DI DESA BETTENG
}

\author{
(Health Cadre Training About Early Detection Of Stunting \\ Toddler In Betteng Village)
}

\author{
Eva Yuliani ${ }^{1}$, Immawanti ${ }^{1}$, Junaedi Yunding ${ }^{2}$, Irfan $^{1}$, Masyita Haerianti ${ }^{2}$, Nurpadila $^{1}$ \\ ${ }^{1)}$ STIKes Marendeng Majene, Jln. R.A. Kartini Majene \\ ${ }^{2)}$ Universitas Sulawesi Barat, Jl. Sultan Hasanuddin Majene \\ E-mail : awraeva@gmail.com,yundingj05@gmail.com
}

\begin{abstract}
ABSTRAK
Stunting merupakan pertumbuhan fisik tinggi badan yang tidak normal sesuai dengan umur. Stunting atau Bahasa lainnya adalah Gizi buruk kronik merupakan kondisi gizi buruk yang dialami semasa balita yang memiliki dampak yang buruk bagi tumbuh kembang anak. Deteksi dini stunting pada balita merupakan salah satu upaya meningkatkan kualitas anak dan bagian dari tugas para kader kesehatan. Oleh karena itu sangat diharapkan pemahaman dan keterampilan kader dalam melakukan deteksi dini stunting. Dalam hasil pendataan awal, didapatkan jumlah stunting cukup banyak di Desa Betteng yaitu $>40 \%$. Berdasarkan data tersebut Desa Betteng masuk dalam kategori kejadian stunting serius. Tujuan kegiatan ini adalah meningkatkan pemahaman dan keterampilan kader kesehatan dalam melaksanakan deteksi dini stunting. Pelaksanaan kegiatan ini dengan cara memberikan pelatihan tentang stunting, dan cara mendeteksinya. Kesimpulan : peningkatan pemahaman kader kesehatan tentang deteksi dini stunting dapat dilakukan dengan penyuluhan dan pelatihan.
\end{abstract}

\section{Keywords: Stunting, kader kesehatan, Deteksi dini}

\begin{abstract}
Stunting is a physical growth of abnormal height according to age. Stunting or Chronic malnutrition is a condition malnutrition experienced during infants who have adverse effects for child development. Early detection of stunting in toddlers is one of effort to improve the quality of children and part of the duties of health cadres. Therefore, it is desirable for cadre understanding and skill in performing early detection of stunting. In early data collection, the number of stunting quite a lot in Betteng is $>40 \%$. Based on this data, Betteng fall in to the category of serious stunting. The purpose of this activity is to improve the understanding and skills of health Cadres in implementing early stunting detection. Implementation of the activity by providing training on stunting, and how to detect it. Conclucion: improving understanding of health cadres on early detection of stunting can be done by counseling and training.
\end{abstract}

Keywords: Stunting, Health cadre, Early detection 


\section{PENDAHULUAN}

Stunting merupakan salah satu permasalahan gizi yang terjadi di Indonesia. Stunting adalah status gizi yang didasarkan pada indekx Tinggi Badan menurut Umur (TB/U) dengan ambang batas (Z-score) <-2 Standar Deviasi (SD) (Kemenkes, 2017). Dampak dari stunting tidak hanya dirasakan oleh individu yang mengalaminya tetapi juga berdampak terhadap roda perekonomian dan pembangunan bangsa. Hal ini dikarenakan sumber daya manusia yang stunting memiliki kualitas yang lebih rendah dibandingkan dengan sumber daya manusia normal.

Masalah kesehatan masyarakat dianggap berat bila prevalensi stunting sebesar 30-39\% dan serius bila prevalensi stunting $\geq 40 \%$ (WHO 2013). Sulawesi Barat berada pada urutan kedua setalah Nusa Tenggara Barat yaitu sebesar 48,0\%. (KemenKes RI, 2013). Angka kejadian stunting di Sulawesi barat cukup banyak yaitu sebesar $48,0 \%$, dan menurut data dari Riskesdas tahun 2013 di kabupaten majene kejadian stunting sebanyak $58,62 \%$.

Beberapa penelitian menunjukkan bahwa anak yang pada masa balitanya mengalami stunting memiliki tingkat kognitif rendah, prestasi belajar dan psikososial buruk (de Souza, 2015). Bayi yang mengalami severe stunting di dua tahun pertama kehidupannya memiliki hubungan sanat kuat terhadap keterlambatan kognitif dimasa kanak-kanak nantinya (Abubakar, Uriyo, Msuya, Swai, dan Stray-Pedersen, 2012). Kejadian stunting yang berlangsung sejak masa kanak-kanak memiliki hubungan terhadap perkembangan motorik lambat dan tingkat IQ lebih rendah (Ramos, Dumith, dan Cesar, 2014). Penelitian menunjukkan anak (6-23 bulan) yang stunting selain memilki tingkat IQ yang lebih rendah, mereka juga memiliki penilaian lebih rendah pada psikomotor (Adeba, Garoma, Gemede, dan Garoma, 2014) . Koordinasi tangan dan mata, pendengaran, berbicara, dan kinerja jika dibandingkan dengan anak normal (Mantovani, et al., 2016).

Deteksi dan Intervensi Dini stunting merupakan salah satu upaya untuk meningkatkan kualitas anak dan merupakan salah satu program dari Kemenkes RI. Pemantauan dan deteksi stunting anak usia dini merupakan bagian dari tanggung jawab petugas kesehatan puskesmas bekerja sama dengan kader posyandu di wilayah kerjanya masing-masing. Harisman (Zainiah, 2014) menyebutkan bahwa kurangnya pelatihan dan pembinaan untuk meningkatkan ketrampilan yang memadai bagi kader menyebabkan kurangnya pemahaman terhadap tugas kader.

Berdasarkan uraian di atas memotivasi penulis untuk melakukan peningkatan pemahaman kader tentang deteksi dini stunting pada anak balita dengan cara melakukan pelatihan dan pendampingan deteksi di Posyandu wilayah Desa Betteng, Kecamatan Pamboang, Kab, Majene.

\section{TUJUAN}

a. Meningkatnya pengetahuan dan pemahaman mengenai manajemen Deteksi Dini dan Intervensi Dini Stunting pada anak balita khususnya anak yang berusia dibawah 2 tahun

b. Bertabahnya keterampilan kader akan mendukung upaya pemantauan kesehatan dan pengendalian stunting pada anak.

c. Optimalnya pelaksana deteksi dini dan intervensi dini tumbuh kembag balitan di posyandu.

\section{PELAKSANAAN}

a. Identifikasi jumlah balita dan masalah stunting.

Identifikasi jumlah balita di desa Betteng (4 dusun)beserta jumlah balita yang mengalami stunting dilaksanakan secara serentak dan didapatkan data sebagai berikut: dusun Timbogading 25 balita 4 diantaranya mengalami stunting, Timbogading Utara 32 balita 23 diantaranya mengalami stunting, Galung 26 balita dan 11 diantaranya mengalami stunting dan Galung selatan 16 balita, 6 diantaranya mengalami stunting. Dalam hasil pendataan, didapatkan jumlah stunting adalah $43,8 \%$ dari total jumlah balita usia 1 sampai 5 tahun adalah 99 balita.

b. Pelaksanaan Program :

1 Penyuluhan terhadap masyarakat khususnya kader tentang Deteksi dan Intervensi Dini stunting pada anak 
2 Pemberian materi pelatihan Deteksi dan Intervensi Dini stunting pada anak yaitu bagi Kader Posyandu

3 Pendampingan dalam penerapan deteksi dini dan intervensi dini tumbuh kembang (stunting) kader posyandu (simulasi)

Pelatihan Deteksi Dini Dan Pencegahan Stunting ini di laksanakan pada hari rabu tanggal 21 februari 2018 yang bertempat di Aula Kantor Desa Betteng dimulai pada pukul 08.30 - 17.00 WITA. Kegiatan ini diikuti oleh 30 peserta terdiri dari 15 kader untuk 3 posyandu dan 15 ibu perwakilan dari setiap dusun yang memiliki balita. Materi yang disampaikan adalah yang pertama yaitu tentang stunting (pengertian, penyebab, gejala dan bagaimana cara pencegahan), materi kedua tentang deteksi dini stunting (simulasi pengukuran Panjang Badan (PB) da Tinggi Badan (TB) lalu menyimpulkan status gizi anak yaitu $\mathrm{PB} / \mathrm{TB}$ berdasarkan umur, dan ketiga tentang kebutuhan Gizi pada balita untuk mencegah stunting.

\section{PEMBAHASAN}

Intervensi untuk menurunkan anak pendek harus dimulai secara tepat sebelum kelahiran, dengan pelayanan pranatal dan gizi ibu, dan berlanjut hingga usia dua tahun. Proses untuk menjadi seorang anak bertubuh pendek - yang disebut kegagalan pertumbuhan (growth faltering) - dimulai dalam rahim, hingga usia dua tahun. Pada saat anak melewati usia dua tahun, sudah terlambat untuk memperbaiki kerusakan pada tahun-tahun awal. Oleh karena itu, status kesehatan dan gizi ibu merupakan penentu penting tubuh pendek pada anak-anak (Unicef Indonesia, 2012).

Pelatihan deteksi dini stunting yang dilakukan selama 2 hari dengan diikuti 30 peserta, melaksnakan kegiatan berupa penyuluhan tentang stunting, melaksnakan pengukuran panjang badan (untuk usia $<2$ tahun) dan tinggi badan (untuk usia > 2 tahun).

Hasil wawancara dengan beberapa peserta menunjukkan bahwa : pengetahuan kader tentang stunting masih sangat rendah, bahkan sebagian besar peserta tidak mengetahui apa itu stunting. Menurut penyampaian beberapa kader, dikatakan bahwa pengkuran panjang badan (PB) dan tinggi badan (TB) pada balita jarang dilakukan, yang paling rutin dilakukan adalah pengukuran berat badan. Pemahamn kader akan pentingnya melakukan pengukuran $\mathrm{TB}$ dan PB masih sangat kurang. Iswarawanti (2010) mengemukakan bahwa secara teknis, tugas kader kesehatan/kader posyandu dalam keterkaitannya dengan gizi adalah kader melakukan penimbangan BB serta melakukan pengukuran $\mathrm{PB}$ dana tau TB balita, lalu mencatat hasilnya dalam buku/Kartu Menuju Sehat (KMS) masingmasing balita tersebut, pemberian makanan tambahan, memberikan vitamin A, melakukan diskusi dan penyuluhan terkait gizi serta melakukan kunjungan ke rumah ibu yang memiliki balita. Kader juga diharapakn dapat berperan aktif dan mampu menjadi sumber informasi serta pemberi dukungan dan mejadi motivator bagi masyarakat (Adistie, dkk, 2017). Melihat pentingnya peran kader dalam masyarakat khususnya terkait gizi pada balita, maka hasil penelitian diatas menjadi perhatian khusus bagi petugas kesehatan.

Faktor internal dan faktor eksternal sangat mempengaruhi tingkat pengetahui seseorang. Notoatmodjo (2010) menjelaskan bahwa faktor yang berhubungan dengan kurangnya pengetahuan antara lain adalah: minimnya dalam keterpaparan informasi, kurangnya hapalan/daya ingat, salah memberikan tafsiran terhadap suatu informasi, adanya keterbatasan informasi serta keterbatasan kognitif dalam mencerna informasi, kurang minat untuk belajar dan tidak familiar terhadap sumber informasi. Kader yang pendidikannya rendah akan lebih sulit untuk menerima arahan dalam pemenuhan gizi dan mereka sering tidak mau atau tidak meyakini pentingnya pentingnya pemenuhan kebutuhan gizi atau pentingnya pelayanan kesehatan lain yang menunjang dalam membantu pertumbuhan dan perkembangan anak (Adistie dkk, 2017). Kader dan keluarga dengan latar belakang pendidikan rendah juga seringkali tidak dapat, tidak mau, atau tidak meyakini pentingnya penggunaan fasilitas kesehatan yang dapat menunjang pertumbuhan dan perkembangan anaknya. Hasil analisah ini sejalan dengan kesimpulan penelitian yang dilakukan oleh Rahayu et al., (2016), yang 
mengatakan bahwa tingkat pendidikan menentukan seseorang mudah atau tidaknya dalam menyerap dan memahami informasi tentang pengetahuan gizi yang mereka peroleh.

Peserta kader yang hadir saat pelatihan sebagian besar berada pada rentang usia dewasa awal dan pertengahan. Semakin cukup umur seseorang, maka tingkat kematangan dan kekuatan orang tersebut akan lebih matang dalam menyerap informasi, berpikir dan bekerja, dan dari segi kepercayaan yang dipercayai oleh masyarakat, seseorang yang lebih dewasa lebih bisa dipercaya dari orang yang lebih tinggi kedewasaannya. Daya tangkap dan pola pikir akan semakin berkembang dan pengalaman hidup yang diperoleh semakin banyak (Wawan \& Dewi, 2010).

Faktor eksternal yang dapat mempengaruhi pengetahuan terkait stunting pada balita adalah salah satunya keterpaparan kader terhadap informasi terkait stunting pada balita. Informasi terkait stunting pada balita dapat diperoleh kader salah satunya dari kegiatan penyuluhan dan pelatihan. Berdasarkan hasil wawancara dengan kader 25 dari 30 orang tidak pernah mendengar stunting, dan belum pernah mendapatkan penyuluhan maupun pelatihan tentang stunting pada balita. Pelatihan kader akan meningkatkan terkait gizi khususnya stunting pada balita memebrikan dampak yang positif terhadap kemampuan kader dalam melakukan deteksi dini terkait stunting. Notoatmojo (2010), mengemukakan bahwa pemberian informasi akan meningkatkan pengetahuan sehingga dapat menimbulkan kesadaran dan akhirnya mengahsilkan cara berpikir sesuai dengan pengetahuan tersebut sehingga terdapat perubahan berperilaku sesuai dengan pengetahuan yang dimiliki.

Lamanya menjadi kader posyandu tidak menjadi faktor penentu dalam pengetahuan kader terkait stunting pada balita. Berdasarkan hasil wawancara dengan peserta pelatihan, didapatkan rentang waktu lamanya menjadi kader bervariasi, mulai dari 2 tahun hingga lebih dari 10 tahun. Kader yang telah berpengalaman lebih dari 10 tahun tidak mengetahui apa itu stunting, begitupun kader yang baru tergabung dalam anggota kade posyandu. Hasil penelitian yang dilakukan oleh Sukiarto (2017) di Magelang tentang pengaruh pelatihan dengan metode belajar berdasarkan masalah terhadap pengetahuan dan keterampilan kader dalam kegiatan posyandu ditemukan sebanyak $(74,3 \%)$ telah menjadi kader posyandu selama 1-5 tahun. Hasil uji analisis didapatkan bahwa tidak terdapat hubungan antara lama menjadi kader posyandu dengan perilaku kader dalam penyempaian informasi kepada masyarakat tentang gizi yang baik dan seimbang. Selain hal tersebut kurangnya sarana dan prasarana menjadi faktor yang mempengaruhi tidak optimalnya penyempaian informasi terkait gizi khususnya kejadian stunting kepada keluarga, seperti lokasi dan tempat yang digunakan untuk penyuluhan, media penyuluhan yang terbatas, lokasi yang tergolong sempit dan tidak representative untuk dilakukan penyuluhan atau diskusi terkait gizi bersama dengan keluarga (Sukiarto, 2017).

Setelah dilakukan pelatihan dilakukan evaluasi terhadap pengetahuan peserta berupa peratnyaan langsung dengan semua peserta, didapatkan $30(100 \%)$ peserta mengetahui tentang stunting, penyebab, tanda gejala. Setelah itu dilakukan simulasi (tes simulasi pertama) bagaimana cara melakukan pengukuran PB dan TB lalu melakukan analisis dengan menggunakan grafik status Gizi dari WHO (PB/TB berdasarkan umur). Dari hasil simulasi pertama didapatkan bahwa 20 dari 30 peserta bisa melakukan analisis status gizi anak (stunting atau tidak). Kemudian dilakukan simulasi kedua dan didapatkan 30 peserta bisa melakukan deteksi stunting pada balita.

Menurut Notoatmojo (2010) setelah seseorang mengalami stimulus atau objek kesehatan, kemudian mengadakan penilaian atau pendapat terhadap apa yang diketahui, proses selanjutnya diharapkan dapat melaksanakan atau mempraktikan apa yang diketahui dan disikapi. Pendidikan kesehatan salah satunya dengan pelatihan merupakan proses perubahan, yang bertujuan untuk mengubah individu, kelompok dan masyarakat menuju hal-hal yang positif secara terencana melalui proses belajar. Perubahan tersebut mencakup pengetahuan, sikap dan keterampilan melalui proses belajar. 


\section{KESIMPULAN}

Kesimpulan yang didapatkan dari kegiatan pengabdian masyarakat di Desa Betteng yakni:

a. Meningkatnya pengetahuan dan pemahaman kader posyandu mengenai Deteksi Dini stunting pada anak balita.

b. Bertambahnya Keterampilan kader posyandu dalam melaksanakan deteksi dini status gizi kronik (stunting) pada balita

\section{SARAN}

Perlu dilakukan follow up terhadap keterampilan kader dalam melaksanakan deteksi dini stunting. Dinas Kesehatan dan instansi-instansi lain yang terkait dapat memberikan solusi atau membuat kebijakan dalam rangka memperbaiki status gizi balita khususnya stunting, seperti mewajibkan setiap puskesmas untuk memantau setiap pertumbuhan dan perkembangan balita, tidak hanya berat badannya saja melainkan tinggi badannya juga dalam rangka memperbaiki status gizi balita khususnya stunting dan menerapkan Program Gerakan Nasional Sadar Gizi dalam Rangka 1000 Hari Pertama Kelahiran untuk meningkatkan status gizi balita stunting.

\section{UCAPAN TERIMA KASIH}

Ucapan terima kasih kami sampaikan kepada para kader diwilayah kerja Posyandu Desa Betteng yang telah bersedia menjadi peserta pelatihan, juga kepada pihak Puskesmas Pamboang Kabupaten Majene atas kerjasamanya. Kegiatan pengabdian kepada masyarakat ini mendapat dukungan dana dari Pemerintah Desa Betteng dan dari STIKes Marendeng Majene.

\section{DAFTAR PUSTAKA}

Abubakar, A., Uriyo, J., Masuya, S.E., Swai, M., \& Stray-Pedersen, B., 2012. Prevalence and risk factors for poor nutritional status among children in the Kilimanjaro Region of Tanzania. International Journal of Environmental Research and Public Health. 9, 35073518.

Adeba, A., Garoma, S., Gemede, H.F., \& Garoma, W., 2014. Prevalence of stunting and associated factors of children among 6-59 bulan age in Guto
Gida Distric, East Wollega Zone, Oromia, Ethiopia. Food Science and Quality Management. 29, 1-18.

Adistie, F., Maryam, N.N.A., \& Lumbantobing., 2017. Pengetahuan kader kesehatan tentang deteksi dini gizi buruk pada balita. Dharmakarya: Jurnal aplikasi Ipteks Untuk Masyarakat, 6(3)173-177

Iswarawanti, D. N., 2010. Kader posyandu : Peranan dan tantangan pemberdayaannya dalam usaha peningkatan gizi anak di Indonesia. Journal Manajemen Pelayanan Kesehatan, 13(04).

Kementerian Kesehatan RI., 2017. Data Pusat Informasi Profil Kesehatan Indonesia . Jakarta: Kementerian Kesehatan RI.

Kementrian Kesehatan Republik Indonesia., 2013. Riset kesehatan dasar (RISKESDAS) 2013. Jakarta: Kementrian Kesehatan Republik Indonesia.

Mantovani, S.A.S., Ramalho, A.A., Pereira, T.M., Branco, F.l.C.C., Oliart-Guzman, H., Delfino, B.M., ....\& Da SilvaNunes, M. 2016. Stunting in children under five years old is still a health problem in the Western Brazilian Amazon: A population-based study in Assis Brasil, Acre, Brazil. Ciencia \& Saude Colectiva. 21(7), 2257-2266.

Notoatmodjo. S., 2010. Promosi Kesehatan : Teori dan Aplikasi. Jakarta: PT Rineka Cipta

Rahayu, A. Yulidasari, F. Putri, A.O, Rahman, F. Rosadi, D., 2016. Faktor Risiko Yang Berhubungan Dengan Kejadian Pendek Pada Anak Usia 6-24 Bulan. Jurnal Kesehatan Masyarakat. 11 (2), 96-103.

Ramos, C.V., Dumith, S.C., \& Cesar, J.A. 2015. Prevalence and factors associated with stunting and excess weight in children aged 0-5 years from the Brazilian semi-arid region. $J$ Pediatr. 91(2), 175-182.

Sukiarto, E., 2017. Pengaruh pelatihan dengan metode belajar berdasarkam 
masalah terhadap pengetahuan dan keterampilan kader gizi dalam kegiatan posyandu: studi di Kecamatan Tempuran Kabupaten magelang. Dalam tesis pada Program Pascasarjana Gizi Masyarakat Universitas Diponegoro Semarang tahun 2017.

Unicef Indonesia., 2012. Ringkasan Kajian Gizi Ibu dan Anak. Diunduh tgl 3 Juli 2017 dari https://www.unicef.org/indonesia/id/A6 _-_B_Ringkasan_Kajian_Gizi

Wawan, A., \& Dewi, m., 2010. Teori dan Pengukuran Pengetahuan, Sikap dan Perilaku Manusia. Yogyakarta: Nuha Medika.

WHO., 2013. Childhood stunting: Context, causes and consequences. WHO.

Zainiah, N., 2014. Hubungan frekuensi pelatihan yang diikuti kader dengan tingkat keterampilan kader dalam pelayanan posyandu balita di Desa Nogotirto Gamping Sleman Yogyakarta (Online) (http://www.opac.say.id). 